\title{
Social Media and Political Participation: An Investigation of Small Scale Activism in Greece
}

\author{
Alex Afouxenidis \\ National Centre for Social Research, Athens, Greece \\ Email: afouxenidis@ekke.gr
}

Received November $3^{\text {rd }}, 2013$; revised December $3^{\text {rd }}, 2013$; accepted December $10^{\text {th }}, 2013$

\begin{abstract}
Copyright (C) 2014 Alex Afouxenidis. This is an open access article distributed under the Creative Commons Attribution License, which permits unrestricted use, distribution, and reproduction in any medium, provided the original work is properly cited. In accordance of the Creative Commons Attribution License all Copyrights (C) 2014 are reserved for SCIRP and the owner of the intellectual property Alex Afouxenidis. All Copyright @ 2014 are guarded by law and by SCIRP as a guardian.
\end{abstract}

This paper discusses the possibilities and limitations of online activism. The example used to illustrate the above point provides some evidence that, on some occasions, civil society maybe mobilized through the use of the internet and the online public sphere, to organize more coherent and practical political demands. At the same time, it is also shown that the capacity of individuals to fully participate depends on previous offline experiences as well as a relatively higher degree of technical competence.

Keywords: Civil Society; Digital Activism; Political Engagement; Social Networking

\section{Introduction}

Power relations remain fundamental for the construction of contemporary societies. Alongside these, come specific types of institutional arrangements which exist in order to smooth the edge to unequal forms of representation (Drake, 2010). One of the main arguments used connected to the enhancement of liberal democracies, is connected to the idea of reinvigorating the public sphere through the use of new technology and the web.

Subsequently, the basic question of this paper is whether online group formation has helped to foster political engagement and participation among individual citizens, civil society organizations and other similar associations in contemporary Greece, especially under the current circumstances of severe economic crisis (Afouxenidis \& Kavoulakos, 2012) ${ }^{1}$. To this end, an internet questionnaire was used, in order to assess the overall impact of online/offline political participation and political engagement through the use of social networking groups. The target group of this particular research consisted of unemployed university lecturers who, almost four years ago, after being appointed by university committees to their respective departments, were still not in employment ${ }^{2}$. The study took place between January and February 2012. The respondents were 159 out of a possible 350. About 65\% were male and almost $60 \%$ were between the ages of 35 to 45 years old. The

\footnotetext{
${ }^{1}$ Unemployment in Greece is almost $30 \%$ and youth unemployment is almost $65 \%$. For more information see,

http://www.ekathimerini.com/4dcgi/ w articles wsite1 1 30/08/2013 516 $\underline{279}$ and

http://www.telegraph.co.uk/finance/financialcrisis/10230653/Greek-youth-u nemployment-soars-to-64.9pc.html.

${ }^{2}$ See,

http://www.theguardian.com/science/blog/2013/jun/20/hundreds-young-sch olars-held-hostage-greek.
}

main idea was to examine the relationship between the participants to the web, as a whole, and whether they engaged in political activity offline as a result of becoming relatively active online.

\section{Political Participation, Internet and Social Media}

Greece has an estimated overall number of over 5 million internet users, about 4 million facebook users ${ }^{3}$ and a significant number of bloggers. This type of social media and internet penetration served as a likely case to study whether social networking has restructured the face of political participation. The participants in this study, are generally well-educated, young to mid-age and relatively comfortable using the Internet. This increased the probability of finding individuals and/or groups engaged in digital activism, therefore gaining a more comprehensive understanding of the distinction between online and offline political behaviour.

Despite the general and persisting trends regarding global and regional digital inequality (Loader, 1998; ITU, 2012; Leontidou, Afouxenidis, et al., 2013), during the first decade of the $21^{\text {st }}$ century, social networks have become integrated into everyday life and practice for millions of people and organizations around the world. A significant number of theoretical and empirical studies in the social sciences are starting to form a picture of how this widely spread form of communication affects constitutional democracy and political participation (Graham \& Martin, 1996; Gustafsson, 2012; Harlow, 2012; Hepburn, 2012; Fuchs, 2012; Castells, 2012; Bakardjieva, Svensson, \& Skoric, 2012) and possibly transforms the rules and methods of political engagement.

${ }^{3}$ This figure is taken from http://www.internetworldstats.com/stats9.htm, accessed on 14/03/2013. 


\section{A. AFOUXENIDIS}

An ongoing discussion in current research is concerned with the question of whether the level of political participation in the industrialized or post-industrial world is low. The academic debate is split into two main arguments. Firstly, Putnam (2000) argued that political participation is decreasing as the level of social capital in society decreases and political apathy increases. On the other hand, (Dalton, 2008; Dahlgren 2009) it has been suggested that political participation is merely changing, taking new forms, as post-materialist values (Inglehart, 1977) become more salient, with social capital being readjusted. Consequently, instead of, for example becoming members of political parties and other such formal organizations, citizens are now engaged outside of the traditional political system (Micheletti, 2003).

Since the rapid spread of internet connections in the 1990s, social science has increasingly turned its eyes towards examining the web as a mechanism of a more democratic future or, as a process which acts as yet another catalyst in terms of concentrating power into the hands of the few (Hindman, 2008). The development of applications often referred to as Web 2.0 and social media over the past ten years, combined with evidence of new forms of rapid networked mobilization (Castells, 2001; Atton, 2003), created a renewed interest in the effects of technology on civic activism and overall political participation. There is a sort of historical element throughout various analyses which spans for a period of over 25 years at least: initially, during the 1990s, the web was discussed primarily as a sort of cyberspace (Featherstone \& Burrows, 1995; Star, 1995; Jones, 1995; Aronowitz, Martinsons, \& Menser, 1996). This was also exposed in popular culture via movies such as the Matrix and others, which explored this idea to the fullest and which presented a kind of post-apocalyptic dystopian future. In addition, technological development was also critically examined by questioning the assumptions that it will necessarily lead to better times (Finnegan, Salaman, \& Thompson, 1987; Pacey, 1994; Robins \& Webster, 1999). During the 2000s the web was described more as a virtual space which produces and regenerates various sorts of virtual societies and communities. It is only recently, that the "net" has begun to be appreciated more closely to what it actually is, namely another realm of everyday reality. Therefore, in our view, although the distinction offline/ online may still have some methodological validity, it is becoming progressively defunct as a useful analytical tool. It is more interesting to actually examine the two realities in unison rather than in opposition. The evidence of the research presented in this paper attempts to look at the use of the net through the lens described above.

\section{A Note on Theory and Research Methodology}

In our view, advances in computing power increased enormously the possibilities for research within the social sciences fields. It has also helped in gathering and exchanging information quickly across and among different strands of research, thus generating interesting and substantial flows of information and hard data. Additionally, the broad range, scope and volume of data which can be analyzed have also increased.

However, this does not necessarily mean that theorizing, or exploring new ways to do research, has significantly changed within the social and political sciences. More than often, especially with regards to issues such as the one we are exploring here, substantial problems and issues of the academic research community have remained intact. For example, with regards to, say, political sociology and/or sociology in general, the fact that the field has already been broken down into smaller, sometimes highly specialized sub-fields, meant that on many occasions research is not directly related to the basic theoretical strands of contemporary sociological thought (Afouxenidis, 2012). In other words, fragmenting the field coupled by the ever-increasing need for quick answers and responses to various social issues, has lead to a peculiar sort of methodological standardization: individuals or groups of scientists doing research using, more or less, similar or the same techniques irrespective of what is actually being researched. This type of methodological "impoverishment" can be partly explained by the loss of vigorous theoretical argumentation (Turnsek \& Jankowski, 2008).

With regards, to the case of studying the net and/or social media, a number of interesting observations can be made. In general, research remains fragmented and highly empiricist. Research techniques are generally based on gathering huge volumes of data, often with no real consideration on their actual validity, such as what sort of evidence can be usefully utilized, or how and in what ways web data can be correlated to nonweb data. Also, comparative elements which are always pertinent in researching society seem to be missing. For example, researchers and academic institutions have done a lot of work on, say, new social media without accounting for possible similarities and/or differences amongst them. Another example is related to the fact that a lot of net research is primarily focused on the individual actor rather than on the possible collective impact social networking may have on individuals. Thus, issues such as diversity, projection of identity and political behaviour, are simply reflected by researchers rather than critically interrogated. The opportunity to gather large amounts of data, does not necessarily mean that social scientists understand or are able to explain societal organization and behaviour more in depth than previously, especially when adequate theorizing is lacking.

\section{Political Participation: The Case Study}

Underlying the basic research concept was the idea that democratization in the world of inter-connectedness, may reflect new types of political participation compatible with, or even brought about by, technological change.

The current economic and social crisis in Greece, has brought forward elements connected to the theme of political participation which generally involved the urban youth and some particular collectivities, which played an active part in popular mobilizations since the beginning of the crisis. In general, mobilizations shared one basic characteristic: they existed offline and they mobilized by using online technologies as well as traditional methods.

However, the group of unemployed/underemployed university lecturers, presented an interesting differentiation to the above: it became organized mainly because of the creation of an internet platform via which news, ideas and methods of mobilization could be rapidly exchanged.

The main narrative behind the study is connected to the fact that because of the severity of the economic crisis the government decided to freeze all newcomer lecturers from entering the

\footnotetext{
${ }^{4}$ This platform is still active at

http://lecture.jimdo.com/2011/02/27/\%CE\%B1-\%CE\%BB\%CE\%AD\%CE \%BA\%CF\%84\%CE\%BF\%CF\%81\%CE\%B5\%CF\%82-\%CF\%83\%CF\%84 \%CE\%BF-\%CF\%88\%CF\%85\%CE\%B3\%CE\%B5\%CE\%AF\%CE\%BF/
} 


\section{A. AFOUXENIDIS}

university system. These people, spread all over the country, had very little contact with one another and great difficulty in getting together in terms of collectively becoming organized. This study utilized their online platform ${ }^{4}$ to ask them a series of questions via an internet questionnaire in order to examine two basic issues: firstly, whether they are active online and, secondly, whether their level of political participation and activity grew because of using the net. This is a target group oriented study which looks at people who have a rather high educational background and who use the net on a, more or less, daily basis. In order to correlate our online evidence we also conducted a series of offline interviews with people who played a major role behind organizing the whole group.

The interviews indicated that individuals who had no previous experience of collective action, came together almost by chance, via looking up information over the net primarily focusing on the legal aspects of the government's actions. In other words, the net was the instrument that brought them together and it was over the net that they exchanged e-mails and personal info. They, very quickly, decided to meet offline and organize as a collective group. They subsequently decided to build up a net site which in turn, became the major tool for disseminating info, exchanging ideas and organizing various offline events. After the site was created membership grew rapidly demanding their rights from the government in a more substantial and organized manner. Evidence from the questionnaire shows clearly that a huge majority (almost 95\%) say that the group would not have existed without the net site. In terms of everyday organizational functioning of the group, almost everything is done online: informing the members, exchanging ideas via the blog and the forum and holding virtual meetings to decide on future activities.

The main quantitative findings of the research briefly indicate the following:

- Individuals are in the net every day, mostly for professional reasons. Only 9\% used the net for connecting to social media. Therefore, net penetration is high but that is not reflected onto social media penetration.

- They use the net mostly as consumers rather than as creators of their own material. For example, $76 \%$ stated that they never post messages relating to political content.

- They also seem to participate more in activities such as online petition signing.

- A significant number of people (42\%) became informed about the creation of the group via the net.

- Almost $87 \%$ said that they remain "ordinary members" of the group.

- About 74\% stated that they never belonged to any political party or such similar organization.

- About $46 \%$ said that they never belonged to any other sort of collective organization, such as an environmental or political movement, etc.

- Almost 70\% said that they have never been members of any civil society organizations, NGO's, etc.

The above evidence show that in general, people have had a relatively low level of offline political participation and activity which did not substantially improve because of net use. However an interesting point arose when we asked whether their participation in the group increased the time they spend on the net and by default whether it has improved their knowledge on political and current affairs. About $22 \%$ responded positively to the first question, and interestingly enough, almost $47 \%$ said that they feel more informed via their participation in the group.

A number of respondents were positive when prompted to indicate whether they feel more positively inclined to participate in public activities which have a political context. These are people who used to be active in the past and who became interested in political participation again due to the existence of the group's site. Their four main characteristics are as follows:

- Individuals who post political messages over the net and social media.

- Individuals who participate in mailing lists.

- Individuals who write in forums.

- Individuals who regularly visit web pages of various social movements.

In general, it seems that people who had experience in collective action and/or direct political participation in the past and who for various reasons were inactive, became interested again because of the use of the group's net site.

\section{Conclusion}

Evidence is unclear on whether the use of the net and/or social media with respect to political participation actually enhances activity and generates new forms of democratic engagement. While it is highly noteworthy that online participation is the major cause for the generation of an offline collective organizational form, evidence also points to the fact that use of the net is ephemeral and does not alter significantly the basic "political discourse" of individuals. Although, for example, it may slightly increase political knowledge, this does not mean increased levels of participation which strongly correlate to net use. Social movements and active individuals have existed before the era of mass communication just as they do today. In addition, a number of significant issues have come to the forefront such as whether community engagement and participation changes because of digital transformation and whether political communities actually become more active through the use of social media. Therefore, what precisely it means to be politically active on or off the net, and whether democratic processes are enhanced because of the net are questions for further research and investigation.

\section{REFERENCES}

Afouxenidis, A., \& Kavoulakos, K. (2012). New forms of political participation and mobilization via the use of social media in contemporary Greece. IPSA XXII World Congress of Political Science, Madrid, 8-12 July 2012.

Afouxenidis, A. (2012). Social theory in times of crisis. In A. Afouxenidis (Ed.), Inequality in times of crisis: theoretical \& empirical observations (pp. 17-24). Athens: Propobos Publications.

Aronowitz, S., Martinsons, B., \& Menser, M. (1996). Technoscience and cyberculture. New York: Routledge.

Atton, C. (2003). Reshaping social movement media for a new millenium. Social Movement Studies, 2, 3-15. http://dx.doi.org/10.1080/1474283032000062530

Bakardjieva, M., Svensson, J., \& Skoric, M. (2012). Digital citizenship and activism: Questions of power and participation online. Journal of e-Democracy, 4, i-iv.

Castells, M. (2001). The internet galaxy: Reflections on the internet, business and society. Oxford: Oxford University Press.

Castells, M. (2012). Networks of outrage and hope. Social movements in the internet age. Cambridge: Polity Press.

Dahlgren, P. (2009). Media and political engagement: Citizens, communication and democracy. Cambridge: CUP.

Dalton, R. (2008). Citizenship norms and the expansion of political 


\section{A. AFOUXENIDIS}

participation. Political Studies, 56, 76-98. http://dx.doi.org/10.1111/j.1467-9248.2007.00718.x

Drake, M. (2010). Political sociology for a globalizing world. Cambridge: Polity Press.

Featherstone, M., \& Burrows, R. (1995). Cyberspace, cyberbodies, cyberpunk: Cultures of technological embodiment. London: Sage.

Finnegan, R., Salaman, G., \& Thompson, K. (1987). Information technology: Social Issues. London: Hodder \& Stoughton.

Fuchs, C. (2012). Some reflections on manuel Castells' Book networks of outrage and hope. Social movements in the internet age. Triple $C$, $10,775-797$.

Graham, S., \& Marvin, S. (1996). Telecommunications and the city: Electronic spaces, urban places. London: Routledge. http://dx.doi.org/10.4324/9780203430453

Gustafsson, N. (2012). The subtle nature of Facebook politics: Swedish social network site users and political participation. New Media Society, 14, 1111-1127. http://dx.doi.org/10.1177/1461444812439551

Harlow, S. (2012). Social media and social movements: Facebook and an online Guatemalan justice movement that moved offline. New Media \& Society, 14, 225-243.

http://dx.doi.org/10.1177/1461444811410408

Hepburn, P. (2012). Is this local e-democracy? How the online sphere of influence shaped local politics. Journal of e-Democracy, 4, 45-66.

Hindman, M. (2008). The myth of digital democracy. Princeton: Princeton University Press.

Inglehart, R. (1977). The Silent Revolution: Changing values and political styles among Western publics. Princeton: Princeton University
Press.

International Telecommunications Union (ITU) (2012). Measuring the Information Society. Geneva, Switzerland.

Jones, S. (1995). Cybersociety: Computer-mediated communication and community. London: Sage.

Leontidou, L., Afouxenidis, A., Gialis, S., \& Stringli, A. (2013). Persisting digital society territorial divides. In R. Gonzalez (Ed.) European regions in the strategy to emerge from the crisis (pp. 101-117). Santiago de Compostela: Universidade de Santiago de Compostela.

Loader, B. (1998). Cyberspace divide: Equality, agency and policy in the Information Society. London: Routledge. http://dx.doi.org/10.4324/9780203169537

Micheletti, M. (2003). Political virtue and shopping: Individuals, consumerism, and collective action. Basingstoke: Palgrave. http://dx.doi.org/10.1057/9781403973764

Pacey, A. (1994). The culture of technology. Cambridge, MS: MIT Press. Putnam, R. (2000). Bowling Alone: The Collapse and Revival of American Community. NY: Simon \& Schuster.

Robins, K., \& Webster, F. (1999). Times of the technoculture. London: Routledge.

Star, S. (1995). The cultures of computing. Oxford: Blackwell.

Turnsek, M., \& Jankowski, N. (2008). Social media and politics: Theoretical and methodological considerations in designing a study of political engagement. Politics: Web 2.0: An International Conference New Political Communication Unit Royal Holloway, University of London, 17-18 April 2008. 